Western University

Scholarship@Western

Aboriginal Policy Research Consortium International (APRCi)

$12-2006$

\title{
Aboriginal women working in vocational training and education: a story from Central Australia
}

Kate Lawrence

Waltja Tjutangku Palyapayi Aboriginal Association

Follow this and additional works at: https://ir.lib.uwo.ca/aprci

Part of the Civic and Community Engagement Commons, Service Learning Commons, and the Social Welfare Commons

Citation of this paper:

Lawrence, Kate, "Aboriginal women working in vocational training and education: a story from Central Australia" (2006). Aboriginal Policy Research Consortium International (APRCi). 427.

https://ir.lib.uwo.ca/aprci/427 
This article was downloaded by: [University of Western Ontario]

On: 07 December 2012, At: 10:33

Publisher: Routledge

Informa Ltd Registered in England and Wales Registered Number: 1072954 Registered

office: Mortimer House, 37-41 Mortimer Street, London W1T 3J H, UK

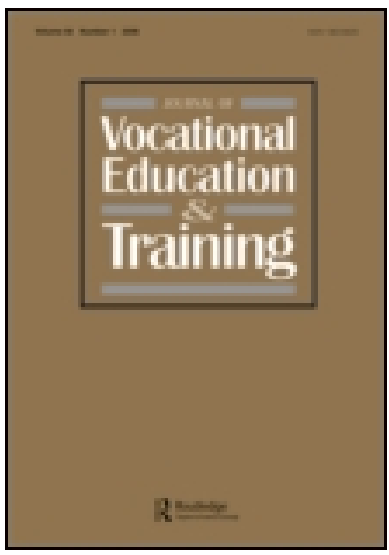

\section{J ournal of Vocational Education \& Training}

Publication details, including instructions for authors and subscription information:

http:// www.tandfonline.com/loi/ rjve20

\section{Aboriginal women working in vocational training and education: a story from Central Australia}

Kate Lawrence ${ }^{\text {a }}$

a Waltja Tjutangku Palyapayi Aboriginal Association, Australia Version of record first published: 01 Dec 2006.

To cite this article: Kate Lawrence (2006): Aboriginal women working in vocational training and education: a story from Central Australia, J ournal of Vocational Education \& Training, 58:4, 423-440

To link to this article: http:// dx.doi.org/ 10.1080/ 13636820601005545

\section{PLEASE SCROLL DOWN FOR ARTICLE}

Full terms and conditions of use: http://www.tandfonline.com/page/terms-andconditions

This article may be used for research, teaching, and private study purposes. Any substantial or systematic reproduction, redistribution, reselling, loan, sub-licensing, systematic supply, or distribution in any form to anyone is expressly forbidden.

The publisher does not give any warranty express or implied or make any representation that the contents will be complete or accurate or up to date. The accuracy of any instructions, formulae, and drug doses should be independently verified with primary sources. The publisher shall not be liable for any loss, actions, claims, proceedings, demand, or costs or damages whatsoever or howsoever caused arising directly or indirectly in connection with or arising out of the use of this material. 


\title{
Aboriginal women working in vocational training and education: a story from Central Australia
}

\author{
Kate Lawrence* \\ Waltja Tjutangku Palyapayi Aboriginal Association, Australia
}

\begin{abstract}
This article outlines research undertaken by an Aboriginal women's non-government organization (NGO) into vocational training and education (VTE) needs and issues for remote Aboriginal communities in Central Australia. It describes the Central Australian context, and in particular the impact of remoteness, inequity and disadvantage upon Aboriginal people's access to and participation in VTE. Waltja Tjutangku Palyapayi (Waltja) is an Aboriginal NGO based in Alice Springs, at the centre of the desert region of inland Australia. Waltja supports the development of family services and the self-determination of remote Central Australian Aboriginal communities. Senior Aboriginal women from widespread communities govern Waltja. In their communities, and working with and through Waltja, women play a significant role in identification of training needs, advocacy for their communities, and facilitation of education and training, including VTE. This article outlines Waltja's research over the past decade into training needs and issues and documents the organizational 'journey' of this Aboriginal NGO into and within the VTE system. In particular, the article discusses Waltja's 'Training Nintiringtjaku' initiative to develop a professional role for Aboriginal community leaders mediating between the VTE system and their communities.
\end{abstract}

\section{Introduction}

This article documents the work of Waltja Tjutangku Palyapayi Aboriginal Association (Waltja), an Aboriginal women's non-government organization (NGO) in Central Australia. Waltja is governed by senior Aboriginal women, supporting the development of family services and the self-determination of remote Central Australian Aboriginal communities. In these communities, and working with and through Waltja, women play a highly significant role in identification of training needs, advocacy for their communities, and facilitation of education and training.

\footnotetext{
*Waltja Tjutangku Palyapayi Aboriginal Association, PO Box 4510, Alice Springs, NT 0871, Australia. Email: training@waltja.org.au
} 
The first section sketches the context for Waltja's work, the conditions in Central Australian remote communities, and the impact of remoteness, inequity and disadvantage upon Aboriginal people's access to and participation in vocational training and education (VTE). The community development principles that Waltja works from are outlined, as are programmemes and initiatives that Waltja has developed. Waltja leaders speak for their families and communities and for women across the region, and they work together to improve conditions and services for remote Aboriginal communities. One of the key issues of concern to Waltja members is education and training, and access to career paths for young people on the communities. This article documents Waltja's key research into training needs, and advocacy for addressing these needs and issues.

The article also documents Waltja's organizational journey as a registered training organization (RTO). In particular, the article addresses Waltja's 'Training Nintiringtjaku' initiative to create a professional pathway into VTE for Aboriginal people working in and for their communities.

\section{The Central Australian context}

Waltja is based in Alice Springs, the regional centre for Central Australia. The focus of all Waltja's activity is not in the Alice Springs urban centre, however, but in remote Aboriginal communities across Central Australia, including the cross-border region of the Northern Territory, South Australia and Western Australia. ${ }^{1}$ The estimated population of Aboriginal people in this area is 13,000, spread over 900,000 square kilometres.

The following snapshot of conditions in remote communities is drawn from the continued documentation of community contexts through Waltja programmes over the past decade (Waltja, 1996, 1999, 2001, 2002; Lawrence, 2005; Young et al., in press)..$^{2}$ It is substantiated by recent research and government publications (SCRGSP, 2005; MCEETYA, 2006). It is significant, however, that so little has changed in the conditions and aspirations for remote communities in the past decade, and that the services that are provided in communities require considerable advocacy and voluntary effort by community members to maintain them at even a minimal level.

\section{Remote communities}

The establishment of remote and relatively small Indigenous 'communities' scattered across the desert region is relatively recent, dating from the homelands movement of the 1960s to 1980s, when Aboriginal family groups moved away from missions and government settlements back to their traditional country. While remote communities enable a close and continuing connection with land and with aspects of traditional culture, life within these communities and their outstations is also marked by locational disadvantage, endemic poverty, ill-health and inadequate housing and services.

The resident numbers in remote Aboriginal communities vary considerably, and fluctuate due to family and cultural obligations, and temporary relocation to urban 
centres to access health, education, banking and other services (Guenther et al., 2005 , p. 18). Seventy-two percent of discrete Indigenous communities in the desert region have a population of less than 50 people (p. 14). Communities with populations ranging from the threshold size of 300 (Waltja, 1999, p. 10) to 500 (Guenther et al., 2005, p. 14) will usually have a community council, a primary school, a health clinic and a local store. Some communities have a women's centre, which may offer or support family services such as aged care, childcare, nutrition programmes, home and community care, and meals on wheels for the elderly and disabled.

Women leaders in remote communities spend a lot of their time, while also caring for their own families, in meetings and voluntary work to maintain these essential community services that urban dwellers take for granted. Community health clinics, schools, childcare services and shops all have community management committees. Each community council manages local government functions including essential services and works programmes. Whilst voluntary governance work enables culturally sensitive and responsive services, Aboriginal community members:

tend to get locked into volunteering without the clear pathways or skills development towards assuming such paid roles. Their depth of skills and knowledge also remains informal, unaccredited and unrewarded. (Young et al., in press)

While Aboriginal people are held responsible for governance of their communities and locally-based services, professional and administrative positions in these services are almost universally held by non-Indigenous people from other areas (Gelade \& Stehlik, 2004).

In remote communities there is a general lack of suitable housing infrastructure, with large numbers in each household living in inadequate conditions. Over $60 \%$ of Indigenous people aged 15 years and over in remote communities are in overcrowded housing, with $21 \%$ of them reporting that overcrowding is a 'personal stressor' (SCRGSP, 2005). Grandmothers are often the primary caregivers for their children and grandchildren, in a context in which little service support is available (Waltja, 1999).

The age demographics of the Indigenous population (15\% of the national population of Aboriginals and Torres Strait Islanders is under the age of 5, compared to 7\% of the whole population; Lawrence, 2005) place additional demands upon Aboriginal women for care of children, and have serious implications for an education system that is currently inadequate for the task of providing basic education for remote community children.

In many communities there is an insufficient number of health staff, inadequate transport and no primary health care focus, and specialist staff are under-resourced. This is in a context in which life expectancy is still 17 years lower for Aboriginal people than non-Aboriginal people (SCRGSP, 2005). Both diabetes and renal disease have a consistently greater prevalence and occur at a younger age in the Aboriginal population. Aboriginal people have a higher prevalence of disability than the rest of the Australian population, especially when barriers to Aboriginal people 
accessing disability services (such as a lack of Indigenous health workers) are taken into account. Children's health and learning is affected by endemic gastroenteritis, scabies, respiratory problems and ear, nose and throat infections. There are also widespread problems with suicide and self-harm, alcohol and substance abuse, violence and family breakdown, all of which are associated with socio-economic disadvantage (Lawrence, 2005; SCRGSP, 2005).

\section{Literacy challenges}

The main language groups spoken in the Central Australian area are Warlpiri, Luritja, Western Arrernte, Eastern Arrernte, Pintupi, Kaytej, Anmatyerre, Alyawarre and Pitjantjatjara. English is not the first language, nor even the second, third or fourth language spoken by most people in the region. However, English is the essential language for dealing with corporate, commercial or government services, and for accessing education, health, legal, training, retail, media, welfare and employment services.

While many local Aboriginal people on the remote communities have good oral English skills, few can read and write English well enough to access complex information. This severely limits access to service provision. When those with limited English try to access services in an unfamiliar environment, organizations can often add to language barriers through a lack of cross-cultural knowledge (Waltja, 1999). Non-Aboriginal people are consistently appointed to professional positions in remote communities, with no competence in the local language nor any professional expectations on them to acquire community language skills (Lawrence, 2005).

Literacy and numeracy proficiency is a critical factor in learning progression beyond the early years of schooling. Literacy and numeracy are described as 'hurdles for Indigenous students', with improvements 'critical to the achievement of Year 10 and 12 retention and attainment' (SCRGSP, 2005, section 7.1). Indigenous primary school students are less likely to achieve Year 3 and 5 literacy benchmarks; Indigenous students of secondary age are half as likely as other students to achieve Year 12; and although Indigenous students are participating at increasingly higher rates in VTE, their pass rates and qualification outcomes remain well below that of non-Indigenous Australians (Guenther et al., 2005).

\section{Access to education and training}

Only about one in twelve Northern Territory larger communities have a secondary school to Year 10 in their community; less than a quarter of Northern Territory desert communities have access to a high school within 50 kilometres (Guenther et al., 2005). To go to high school, most students must leave their communities and board in Alice Springs or other urban centres. As noted by the Ministerial Council for Employment, Education, Training and Youth Affairs (MCEETYA), young Indigenous people who have to leave their communities to undertake secondary studies are disadvantaged by inadequate preparation, and: 
homesickness, distance from family and community support, lack of local support, poor literacy levels, and shame at not succeeding lead many young Indigenous people to drop out. (MCEETYA, 2001)

Retention rates for Indigenous students to Years 9, 10 and 11 are consistently lower than for non-Indigenous students (e.g. a $85.8 \%$ national retention rate to Year 10, compared to $98.5 \%$ for non-Indigenous students in 2004). A dominant factor in early school leaving is achievement levels in literacy and numeracy (SCTGSP, 2005).

In 2004, Indigenous students were enrolled in lower-level VTE qualifications: $30.8 \%$ at Certificate I and II, compared to $13.1 \%$ of non-Indigenous students, and $69.2 \%$ at Certificate III and above, compared to $86.9 \%$ of non-Indigenous students. Completion rates for Indigenous students of the Australian Qualification Framework (AQF) Certificate III and above was $54.7 \%$ in 2004 , compared to $79.5 \%$ for nonIndigenous students (SCTGSP, 2005). These patterns of limited access to postschool VTE qualifications and low Certificate-level opportunities

continue to limit the post-school options and life choices of Indigenous students and perpetuate intergenerational cycles of social and economic disadvantage. (MCEETYA, 2006, p. 11)

In remote settings,

employment opportunities for Indigenous learners are severely limited by an almost complete lack of agencies or industries offering training or employment opportunities .... In the remote localities Aboriginal learners were found to be largely unaware of opportunities for expanding their learning, or for employment. (Gelade \& Stehlik, 2004, p. 9)

A culture of risk-adversity among training organizations has an impact on a lack of training opportunities:

remote delivery is often avoided by training organizations because of high risk in terms of effective consultations, costs of travel and accommodation and problems with attendance, retention and completions. (Young et al., in press)

Occasional VTE programmes on remote communities are generally the only postprimary education opportunities offered on-site, and, as Guenther et al. note, 'assume uneasily the functions of re-engagement and basic education alongside mainstream work-oriented training' (Guenther et al., 2005, p. 14). The English literacy requirements of VTE programmes constitute a continuing barrier to access and effective participation, while the 'compounding effects of poverty, family circumstances, locational disadvantage as well as poor English proficiency' (Guenther et al., 2005, p. 30) constitute continuing barriers to access and achievement in VTE for remote Indigenous communities.

The remote context thus affects registered training organizations through the additional costs involved in remote delivery, the curriculum and staff skills challenges of multi-lingual clients with limited English literacy, and the low levels of Aboriginal employment to which training delivery and outcomes can be linked. Other factors negatively influencing RTOs' delivery choices are a widespread lack of accommodation 
for visiting workers, infrastructure for training delivery, or continued mentoring after the completed 'delivery' of training.

\section{Challenging the deficit analysis}

Within this broad context, the 'flavour of the discourse' about access to and participation within VTE for Aboriginal people living in remote communities is:

infused with notions of disadvantage that resonate as deficit analyses, locating the heart of the problem as residual within the individual or group rather than systemic. Such deficit analyses are also co-located within notions of the 'outback' - the harsh and under-serviced frontier. (Young et al., in press)

The 2004 policy statement by the Federal coalition government, Indigenous Australians: opportunities and responsibility, frames the challenges for remote Aboriginal communities within this deficit model:

In these communities high levels of intergenerational welfare dependency, lower participa-
tion levels, poverty and poor health are endemic. Populations in these communities are
growing dramatically and the situation will worsen if decisive action is not taken. With
opportunities for employment and economic development already limited, these commu-
nities will not be able to cope with projected population increases. Young people should
be given the opportunity to leave these communities and become economically indepen-
dent. (Howard, 2004, p. 7)

The framing by the Howard government of remote Aboriginal communities as dysfunctional and unable to cope with endemic problems bypasses any recognition that remote Aboriginal people have needs and aspirations that do not fit neatly within 'mainstream systems'. Instead, attention to 'how awful female and family conditions are' has been used as 'a stick with which to beat Aborigines [and] their organizations' (Jull, 2004, pp. 6, 26).

Within this context of both locational and systemic disadvantage, Waltja challenges the 'deficit analysis' of remote Aboriginal communities. This is particularly important given recent media and government attention to issues of community governance, petrol sniffing, family violence and child abuse. As Waltja's manager wrote in a recent issue of Waltja's magazine Family Nerws:

There has been a lot of talk in the media about Indigenous affairs in the past month. Some of it has been good but a fair bit of it has been harmful. People are asking us if the government wants to take the children away again, if they want to close all the communities or send the army in. There is confusion and anxiety across all age groups.

The good part is that the whole of Australia now realizes that our families need to be listened to and be a real part of any programmes designed to bring solutions, that issues around child protection, violence and substance abuse are now reaching the big ears. The worry is that Indigenous people will be seen as little more than a financial drain on everyone's pockets and that things never improve. To all of you that have been struggling and working hard to make a change and get a voice please keep going. Don't give up! (King, 2006, p. 1)

When addressing these challenges it is important to acknowledge the cultural strengths of Aboriginal communities, and not just to see the challenges as negatives. 
Living in remote communities is, for many Aboriginal people, living in an appropriate relationship to land, family and tradition, with associated responsibilities for the work of maintaining traditional culture. While paid employment opportunities are limited, people give their time and effort freely to cultural work, as well as to the development of essential services, community services and local governance. The Aboriginal art and culture industry is based upon and continually reinspired by tradition combined with innovation from the remote communities. Central Australian Aboriginal traditional child-rearing practices have been acknowledged and incorporated into innovative childcare strategies, which now inform university training for early childhood professionals (Warrki Jarrinjaku, 2002). To live and work in Central Australia is to be continually inspired by the resilience, creativity and determination of Aboriginal people who live at the intersection of traditional and Western systems; it is also, however, to be aware of how hard Aboriginal people and their advocates must work to overcome systemic disadvantage and to maintain even minimal services.

\section{Waltja Tjutangku Palyapayi Aboriginal Association}

Waltja was incorporated as an Aboriginal Association in 1997 by Central Australian Aboriginal women concerned to maintain support for women's centres and related programmes in remote communities, after Commonwealth funding for the national Indigenous Family Resource Centre programme ceased in 1996. Waltja's work affirms the value and capacity of remote Indigenous communities, advocates for sustainable development of communities, and works to redress the severe social economic and cultural problems that have resulted from:

dispossession of traditional lands, cultural disintegration and social and economic marginalization. (Waltja, 1999, p. 16)

Waltja is governed by a management committee and executive of senior women from remote communities across this region. The management committee is made up of founding members and younger women being mentored for leadership, with two women jointly elected from their communities. The management committee meets four times a year to review programmes and determine policy, with executive meeting each six weeks.

Waltja's constitutional objectives are:

- To provide appropriate transportation, sporting, communications, health and disability, education and homemakers' services to relieve the severe economic disadvantage and social, emotional and spiritual well-being issues experienced by central Australian people. This includes substance misuse, child protection issues, and all forms of violence including suicide and clinical mental illness.

- To provide administrative and related resource and programmes to develop members of the central Australian community's capacity for self-management and selfdetermination.

- To facilitate community participation in the planning, management provision and evaluation of community-based services in the central Australian region. 
- To secure the provision of training, employment and related programmes to alleviate chronic unemployment experienced by central Australian people.

- To represent the views of central Australian families, from children to the elderly, to arrest cultural disintegration within the central Australian community.

- To provide and promote opportunities for members' cultural expression to arrest disintegration within the central Australian community.

- To undertake measures necessary to improve race relations and counter racial vilification and alleviate the social distress experienced by central Australian people.

- To provide resources, administrative and related support to members in the establishment of initiatives and organizations, the objectives of which will reduce the level of sickness, poverty, helplessness and distress experienced by central Australian people.

- Identify opportunities and needs for the enhancement or extension of communitybased services to relieve the reliance on Alice Springs services. (Waltja, 1997)

Waltja supports and prioritizes the leadership of strong Aboriginal women, support for families, the development and extension of community-based services, and local management of and employment in these services. Waltja's core operating principles are that:

- The family is the foundation of the Aboriginal community and Indigenous identity. Service delivery is most effective when it occurs in the context of the broad family as understood by Aboriginal people.

- Direct service delivery is most effective when provided by local community people who have access to training and support to ensure quality service outcomes. Waltja therefore emphasizes the building of partnerships with Aboriginal communities as the most effective way of providing services to respond to identified needs.

- Direct services need to be located within and supported by local communities. Waltja works in the communities it services. Waltja promotes self-reliance and dignity. (Lawrence, 2005, p. 7)

The protocols and procedures used by Waltja to identify, advocate for and act upon community needs and issues are well-established and follow community development principles. First, issues and needs around service provision are identified and workshopped at a community level,

thus ensuring that responses to the issues and needs are directed and owned by community members. (Young et al., in press)

Proposals are then developed by Waltja through existing or new programmes and services or via partnerships with government and non-government agencies.

Training and professional development for Waltja management and executive members and for participating individuals on communities is embedded in all Waltja projects and programmes. This occurs informally through workshop sessions where ideas and information can be discussed in community languages, amongst and across different communities and language groups, and consolidates improved understanding of 'big words', foreign concepts and shifting policy regimes. More formally, management committee and executive members participate in a range of training and development programmes, including governance training, attending conferences and meetings and a host of other skill development opportunities (Young et al., in press). 
Waltja has programmes in youth support, early childhood services and out-of-school hours care, aged care and disability, and nutrition, with all projects supported through research and training. As a community-based NGO, Waltja, like many others, is funded largely through competitive tendering for the delivery of government programmes, and must reconcile government priorities with its own organizational objectives. This as a potential tension for community-driven organizations:

In an era where funding for NGOs is increasingly transforming into purchaser-provider arrangements as competitive tendering and free trade agreements impact on outsourcing arrangements for government services ... the role of NGOs may become increasingly focused on the delivery of government required outcomes that may, or may not, align with NGO established practice or constitutional objectives of the organizations themselves. (Young et al., in press)

Waltja's strong governance structure, within which management committee members strongly advocate for community needs and provide critical evaluation of programmes, has helped the organization to hold to its own objectives and prioritize the needs of community clients.

Although Waltja's scope of activities is wide, it is not a large organization, employing fewer than 20 full-time staff, and continually seeking funding to continue to expand successful programmes. Wherever possible, Waltja provides funds through programmes to support Aboriginal employment on remote communities. All Waltja's work involves travel to the remote communities, hands-on support and training, and working closely with community clients, families, community-based services, townbased agencies and government. Waltja thus has two approaches to supporting remote communities. The first is to work directly with individuals, families and services in communities, and the second is to develop a partnership approach with other agencies, training organizations, research organizations and government, to encourage them to extend their services to more adequately and equitably address the needs and aspirations of the remote communities.

\section{Waltja's identification of training needs}

In their remote communities, and working with and through Waltja, management committee members play a significant role in the identification of training needs, and in advocacy for improved access to education and training for their communities. Waltja members assert a strong commitment to the principles of lifelong learning, as it is entirely consistent with traditional culture, and also with the intergenerational learning needs of communities (Lawrence, 2005).

Waltja has undertaken research from 1993 to the present day into the training needs of remote communities. The outcomes of the research are summarized below. One research method consistently used over this time is the identification of training needs and other issues for remote communities at Waltja management committee meetings. Waltja members travel long distances for these 2- or 3-day meetings, held quarterly. Community mapping exercises are regularly used to show what training has taken place and where the employment opportunities are for Aboriginal people. 
Members work in small groups in their own languages, and then share their information with the whole group in English and 'in language'. They may create paintings to show the current situation and their communities' training aspirations. This research informs Waltja's organizational priorities, and negotiations with government and other training providers.

When funding has been available, Waltja workshops have been conducted specifically to identify or address training issues: this research has focused upon community consultations across the region (Aboriginal Development Unit/Central Australian Family Resource Centre, 1993; Waltja, 2001) or upon specific issues such as the needs of young women (Waltja, 2002) or the needs of women's centre workers (Waltja, 1996).

In 2004 and 2005, through a research partnership with Women in Adult and Vocational Education (WAVE) and Security4Women (S4W), Waltja undertook further research into the knowledge and aspirations of vocational education and training held by Central Australian Indigenous women leaders (Lawrence, 2005). Research participants who were interviewed as part of this research, and whose statements are summarized and quoted in the following sections, include:

- Aboriginal women who undertook training in 2004 and 2005 for potential casual employment within VTE as 'Training Nintiringtjaku' workers (Aboriginal facilitators of training) for their communities (direct quotations from members of this group are identified by the initials $\mathrm{TN}$ );

- Waltja management committee members (direct quotations from members of this group are identified by the initials WMC).

The key issues identified through all of the above-mentioned Waltja research were as follows (adapted from Young et al., in press).

- There is a need for both informal (non-accredited) and formal (accredited) training, with the former providing a conduit into the latter.

- The outcomes of training, that is, the extent it provides a pathway into real work opportunities in communities, are as important as the quality of the training itself.

- Developing the capacity of remote community residents to facilitate training and to act as leaders and mentors for other participants dramatically improves attendance, retention and completion.

- Training delivery models need to allow opportunity for discussions to occur and understandings to be developed, in language, across language groups and with full acknowledgement of the skills and capabilities adult learners bring to any learning context.

- Development of resources for and from participating communities enhances training outcomes.

- There are a range of constraints on training organizations about the training they can provide that can change the direction and ownership of training and thus reduce effectiveness and outcomes. These restrictions include lack of childcare support, travel support and mandatory curricula. 
- Training needs in governance and administration and functional literacies have been identified over many years and only intermittently, if at all, addressed.

- Life skills training, such as home management, nutrition and healthy living, remain top priorities but are now outside the scope of the formal VTE sector.

The consistent concerns of Waltja members and participants in community consultations (ADU/FRC, 1993; Waltja, 2001) have been for:

training which supports employment access for adult Aboriginal people within existing community jobs, and training which supports traineeships and new job opportunities for their young people. (Lawrence, 2005, p. 6)

Their expectations of the VTE system have been that training will be made available and accessible to the remote traditional communities. The point is consistently made that workplace learning and accreditation opportunities exist in even the poorest Aboriginal community, that Aboriginal people need training and support to manage their own services, and that career entry points and pathways are needed for young people.

The Culture and Careers Workshop for young women from remote communities, held in 2002, found that training support needs to be oriented towards enabling young Aboriginal women to gain skills and qualifications for the existing jobs in communities. In addition to equipping them to work in their own communities, training is encouraged which 'opens their eyes', providing them with a wider range of training and employment options than are presently available in their communities (Waltja, 2002).

Waltja management committee members and the participants in the community consultations want improved Aboriginal access to existing jobs in their communities, such as governance, administration, services, community care work, education and health, which are generally taken up by non-Indigenous workers. They also need professional development and accreditation opportunities as volunteers or hourly paid workers within these services. Aboriginal people are generally blocked from employment in the few properly paid employment positions on the communities-in administration and management of services - due to low levels of English literacy and numeracy and limited experience with office technologies and financial management systems.

Of particular concern to all research participants, including the registered training organization representatives, is the need for Aboriginal people to become literate in English in order to succeed in education and gain employment. This is of particular concern in relation to young people, as one management committee member expressed:

I'd like more people to learn English and writing, if they learn English and writing then they can help the old people. ... Take all the boys and teach them to learn what they have got to do. And young girls, teach them to work, education, learning for work, what they do in the communities. People want to learn. (WMC) (Lawrence, 2005, p. 20)

A direct link is drawn between the lack of good educational opportunities and antisocial or self-destructive activities, particularly for young people at risk. Waltja 
members 'worry for their young people if there is no good start for them at school and in teenage years' (Lawrence, 2005, p. 6). They hope for:

a learning pathway for them, to get confidence, competence and employment. They hope that their young women can get work within their own communities, in the store, the Council office, the clinic, the school, the art centre, aged care and child care, living in their own country and working confidently both in their own language and in English. (Lawrence, 2005, p. 6)

All research participants stress the problems of low levels of English literacy, numeracy and experience with computer technologies, and the impact of this on further education or employment opportunities. English language literacy, numeracy and computer literacy are needed by individuals if they are to gain access to or participate effectively in training or employment.

Training is needed in community governance and administration, particularly in regard to working effectively within the governance structures of community councils and community services, the setting up of new community services and community enterprises, making submissions and administering funding and the management of community events ((Lawrence, 2005, pp. 12, 18). The functional literacies of documentation, governance, financial management and contractual compliance are required by community council members and by the boards and managers of community services:

that hard English .... All of those big words [to] understand properly what's going on in Council meetings ... to know how to fill in forms, to understand funding proposals. (TN)

(Lawrence, 2005, p. 20)

Registered training organizations must find a balance between the literacy requirements of particular training packages and other VTE/VET qualifications and the literacy capabilities of their clients. Training and capacity-building need to enable Aboriginal people to gain the competence and confidence required for employment in community-based services and to manage these services, gain recognition for their existing competencies and knowledge and access professional development to further their skills and qualifications.

Two key areas of potential employment for Aboriginal women identified in the 1993 survey and workshops were education and health services. In both these areas, the Aboriginal-identified positions of Aboriginal health worker and Aboriginal education worker provide potential pathways for locals into professional employment (Aboriginal Development Unit/Central Australian Family Resource Centre, 1993). Access to this employment, however, is becoming increasingly dependent upon established competency in literacy, numeracy and technical knowledges. This is a significant reorientation from the original focus upon community liaison work, with opportunities to acquire technical knowledge and functional literacies during employment.

The embedding of English language, literacy and numeracy requirements within curriculum and training packages has the potential to exclude Aboriginal health workers from registration and therefore from continuing professional employment 
(Kral \& Falk, 2004). Adult literacy is noted as a major factor affecting the participation of Indigenous people in primary health care delivery and management.

Young et al. note a significant decline of $25 \%$ in the participation of desert Indigenous peoples in vocational training and education:

a trend at odds with steady increases over the past four years and of significant concern given the impending changes to CDEP and the lifting of Centrelink's remote area exemptions. Whilst there are a number of accredited training providers [operating in and from] Alice Springs ... many are field specific (health, technical, driver training), offer training in residential blocks on campus rather than on-site, cover a small number of communities for longer periods of time ... or deliver in town only. (Young et al., in press)

As a Waltja management committee member expressed it:

It's getting tighter and tougher and we need to get more training but we are getting less. (WMC) (Young et al., in press)

Community consultations and Waltja members identify the need for professional educational support and formal training programmes, but they also emphasize the value of having their own experienced Aboriginal trainers, and the development of resource materials for, and from, their own communities (Lawrence, 2005, p. 12). This is consistent with the assertion of Indigenous community leaders nationally that the involvement of communities themselves is essential in the process of determining community aspirations and needs, and also how they are to be put into practice:

If the communities don't have some 'ownership' over the so-called solution, then it will fall down. (Nossel, 2003, p. 10)

Waltja members appreciate the opportunities to learn leadership and governance skills through their management committee membership and through Waltja workshops. However, they want this training to be available also for others in their communities:

I would like to see other training at our communities ... like how to run a meeting and how to talk to government people to help our community .... Some people don't like to speak up, and they shame, they might think they going to say something wrong, like I do [laughter]. [Now] we can run our own meeting and speak up for our place, maybe also talk to government people for help. It is a really good thing, what we are learning. It is good for people to be able to speak up for their communities. (WMC) (Lawrence, 2005, p. 16)

As both Indigenous and non-Indigenous contributors note in a book on cross-cultural approaches to decision-making on Aboriginal lands, there are many examples of Aboriginal people who are expected to manage enterprises, council finances and grants, but who have never trained in written English or mathematics and do not comprehend Western financial management systems. Such people are continually vulnerable to financial mismanagement and 'a passing parade of unscrupulous traders' (Walsh \& Mitchell, 2002, p. 136).

People do need to know ... That kind of information and knowledge should have been given to Aboriginal people a long time ago. As soon as they were self-managed ... there should have been a couple of years where all those different things were taught to people, 
like meeting procedures, administration and money, and all that. But it wasn't done.

(Walsh \& Mitchell, 2002, p. 180)

Any measures to provide vocational training for communities need therefore to go side by side with measures to address the poverty and disadvantage of remote Aboriginal communities and to support the aspirations of the communities toward self-determination.

\section{Waltja Training Nintiringtjaku initiative}

Waltja became a registered training organization because the members wanted to address the barriers to, and deficiencies of, remote delivery of accredited training, as noted earlier in this article. However, Waltja has had limited scope in the range of formal training services it can deliver, and has gained little more than a toehold in the VTE sector since registration. The policies, procedures, records and reporting required of registered training organizations under the Australian Quality Training Framework impose particular bureaucratic requirements and require considerable staff time for compliance. These demands are particularly challenging for a small, not-for-profit, community-based Aboriginal organization.

Waltja's training delivery has tended to be built into workshops and hands-on support work in the childcare, youth and disability services, through on-the-job training that enhances the confident development of knowledge and skills, and builds on participants' strengths (Young et al., in press). This training provides a pathway into formal accredited training but has not enabled Waltja to access the public funding available for RTOs delivering VTE qualifications. Waltja has also encouraged and supported larger and more 'institutional' registered training organizations to provide accredited training to the numerous remote communities across Central Australia.

'Training Nintiringtjaku' is one initiative that Waltja has undertaken to encourage more, and more effective, remote delivery of training, and to create a professional role for Aboriginal community leaders in facilitating the planning, delivery and evaluation of the training. The name means 'be clever for training' in the Pitjantjatjara language. The Waltja Training Nintiringtjaku initiative has grown from the research conducted by Waltja throughout the past decade, and is intended to support the cross-cultural work that must be done by both RTOs and Aboriginal community clients of VTE if training is to be effective and useful.

The role of Training Nintiringtjaku workers is to assist registered training organizations in the planning and promotion of training programmes, to support learners and trainers through interpretation during training delivery, and to support the community and learners in evaluation and feedback. A Waltja management committee member who participated in training for Training Nintiringtjaku describes it as building on community leadership experience:

We learn a lot of different stuff in the training we are doing now. Make a meeting on a community. We were shown how to go about planning it properly. We will work with RTOs to get training happening on the community so we will organize the meetings and 
everything. We have a lot of prior knowledge too. We have been organizing meetings and talking up for Waltja for a long time now. (Young et al., in press)

Training Nintiringtjaku nominees are required to be strong in English and in community languages and have seniority and cultural authority within their community. They have an interest in training and an understanding of the issues and needs of training participants from their communities. One nominee describes the role as supporting the learning of RTO workers as well as of community members:

The RTOs need help with language. Help to decide when to come. Who to talk to, who should go to training. That's why RTOs want to work with Training Nintiringtjaku workers. They are learning too. We can help explain what training is about when people don't understand. (TN) (Young et al., in press)

Training Nintiringtjaku nominees are acquiring knowledge of the VET system, training packages and delivery options, and it is intended that through training and skills recognition they will gradually acquire trainer and assessor qualifications (the Certificate IV in Training and Assessment). The response from government and RTOs to this initiative has been encouraging but funding must be sought for each new training event, and progress is slow.

The Training Nintiringtjaku initiative is one strategy developed by senior Aboriginal women who focus not just upon their own needs for employment and professional recognition, but on whole-community issues, and upon long-term approaches to community development and cultural survival.

\section{Conclusion}

This article has described a context of disadvantage and barriers that confront remote Aboriginal communities in gaining access to, and successfully participating in VTE and employment. The grim context does not, however, mean that Aboriginal communities lack the capacity for self-determination and the professional employment of their members within, as well as beyond, their communities. Nor does it mean that they lack the desire to participate in training if it is linked to real employment or increased skills and knowledge. Waltja challenges the deficit analysis of Aboriginal communities and argues for a greater role for women as mentors, as advocates and as paid professional workers.

Aboriginal women in remote Central Australian communities recognize the challenges involved in accessing school and vocational education, but they keep going, speaking up for their young people to have schooling and career paths, and for adult Aboriginal people to have their skills recognized and have a chance for professional employment within their communities.

Given the context as sketched in this article, Waltja's aspirations are necessarily large in scale, but constrained by the same conditions that the Aboriginal communities struggle with. As a women's organization, and as an NGO working with remote Aboriginal families, Waltja comes from a particular community development perspective which does not sit easily with the corporate systems required of RTOs, 
nor the 'agency of the government' role intrinsic to Commonwealth and state- and territory-funded programmes. Other NGOs in Central Australia, Indigenous and non-Indigenous, also struggle with the imperative to corporatize and bureaucratize in order to meet government standards for industry accreditation or for government funding contracts.

As a small, not-for-profit organization, Waltja has not yet successfully overcome the procedural hurdles of the national VTE standards and regulatory systems for RTOs, and thus has not completed the transition from community programme-based non-accredited training to accredited vocational training. Nor therefore has Waltja begun to expand into its VTE capacity. This is one reason why Waltja has a strategic focus upon partnerships: with communities and their services, with RTOs, with research organizations and with government.

Waltja recognizes that to be effective, any strategies to address the barriers affecting VTE delivery to, and participation by, remote Aboriginal communities must be done in partnership with Aboriginal communities and must acknowledge the skills, knowledge and experience of community leaders. Training providers need to establish relationships with particular skilled people, work together on a continuing basis, and help to establish relevant and effective training within a confident learning community. Training Nintiringtjaku is an initiative to encourage relationshipsan Aboriginal way-through explicit multi-lingual and intercultural mediation of training.

Writing this article has brought up for me the difference between academic writing and the more direct and interpersonal forms of expression and documentation used by Aboriginal organizations like Waltja. Writing in academic language for unknown international readers is very different from the language of, for example, Waltja's Family News magazine. Prioritizing writing time for reflection and publication is also an issue in the context of the urgent and challenging needs that Waltja, like so many other Central Australian NGOs, constantly faces.

The urgent and challenging needs of remote Aboriginal communities in Central Australia should not be interpreted as a deficit intrinsic to Aboriginal people and their communities. Historical, locational and governmental contexts and processes position Aboriginal people at considerable disadvantage. Aboriginal women leaders continually work to 'reach the big ears' about remote community training and related issues, and to advocate collaborative strategies for improving access, relevance and participation in VTE. As an Aboriginal women's organization, Waltja's partnership approach with government and other training organizations enacts the underpinning philosophy of community development and Indigenous self-determination.

\section{Notes}

1. A discrete Indigenous community is defined as a geographic location, bounded by physical or legal boundaries, and inhabited or intended to be inhabited predominantly (i.e. by more than $50 \%$ of usual residents) by Aboriginal or Torres Strait Island peoples, with housing or infrastructure that is managed on a communal basis (Guenther et al., 2005, p. 14).

2. Copies of Young et al. (in press) are available on request from the present author. 


\section{Notes on contributor}

Kate Lawrence is a training support worker for Waltja Tjutangku Palyapayi Aboriginal Association, a non-government organization and registered training organization governed by senior Aboriginal women from remote communities of Central Australia. Kate has worked as a researcher, lecturer and consultant across the higher education, vocational education and community sectors. Her particular research focus is access and equity in vocational education for women, Indigenous and rural and remote Australians.

\section{References}

Aboriginal Development Unit/Central Australian Family Resource Centre. (1993) Report on the training needs of remote Aboriginal women (Alice Springs, Aboriginal Development Unit, Employment and Training Branch of the Department of Education).

Gelade, S. \& Stehlik, T. (2004) Exploring locality: the impact of context on Indigenous vocational education and training aspirations and outcomes (Adelaide, National Centre for Vocational Education Research). Available online at: http://www.ncver.edu.au/students/publications/ 1477.html (accessed 20 August 2006).

Guenther, J., Young, M., Boyle, A., Schaber, E. \& Richardson, J. (2005) Growing the desert: regional and educational profiles of the Australian desert and its Indigenous peoples. Stage 1 report, February. Available online at: http://www.desertknowledge.com.au/index.cfm?attributes.fuseaction $=$ docReports (accessed 20 August 2006).

Howard, J. (2004) A stronger economy, a stronger Australia: the Howard Government election 2004 policy. Indigenous Australians: opportunity and responsibility. Available online at: http://www.liberal.org.au/2004_policy/Sept17_Indigenous_Australians_-_Opportunity_and_ Responsibility_Policy.pdf (accessed 20 August 2006).

Jull, P. (2004) For a charm of powerful trouble: Australian politics in the cauldron of Aboriginal administration (Brisbane, School of Political Science and International Studies, University of Queensland). Available online at: http://eprint.uq.edu.au/archive/00001086 (accessed 20 August 2006).

King, S. (2006) Welcome to edition 40, Waltja Tjutangku Palyapayi Family News, 40, 1.

Kral, I. \& Falk, I. (2004) What is all that learning for?: Indigenous adult English literacy practices, training, community, capacity and health (Adelaide, NCVER). Available online at: http:// www.ncver.edu.au/publications/1476.html (accessed 14 November 2006).

Lawrence, K. (2005) Helping people to help themselves: a study of training issues for Aboriginal women and their remote communities in Central Australia (Waltja Tjutangku Palyapayi Aboriginal Corporation and Women in Adult and Vocational Education for Security4Women). Available online at: http://www.security4women.com/HelpingPeopletoHelpThemselves_Waltjareport_ Jul (accessed 14 November 2006).

Ministerial Council for Employment, Education, Training and Youth Affairs (MCEETYA). (2006) Australian directions in indigenous education and training, report approved by State, Territory and Commonwealth Ministers for Education and Training at the 20th MCEETYA Meeting, Brisbane, 6-7 July. Available online at: http://www.mceetya.edu.au/mceetya (accessed 20 August 2006).

Nossel, G. (2003) Leadership: how and where does it expand community control?, paper presented at Communities in Control Conference, Moonee Ponds, Victoria, 7 April. Available online at: http:/ /www.ourcommunity.com.au/article/view_article.jsp?articleId=574 (accessed 20 August 2006).

Steering Committee for the Review of Government Service Provision (SCRGSP). (2005) Overcoming indigenous disadvantage: key indicators 2005 (Canberra, Productivity Commission). 
Walsh, F. \& Mitchell, P. (2002) Planning for country: cross-cultural approaches to decision-making on Aboriginal lands (Alice Springs, IAD Press/Jukurpa Books).

Waltja Tjutangku Palyapayi Aboriginal Association. (1996) Women's workshop report: women's centre workers management training, Hamilton Downs, NT, October (Alice Springs, Waltja).

Waltja Tjutangku Palyapayi Aboriginal Association. (1997) Certificate of incorporation of an Aboriginal Association. 24 October (Canberra, Office of the Registrar of Aboriginal Corporations (ORAC), Commonwealth of Australia).

Waltja Tjutangku Palyapayi Aboriginal Association. (1999) Strategic plan 1999-2001 (Alice Springs, Waltja).

Waltja Tjutangku Palyapayi Aboriginal Association. (2001) Report on training needs assessment workshops (Alice Springs, Waltja).

Waltja Tjutangku Palyapayi Aboriginal Association. (2002) Culture and careers workshops for young women, May (Alice Springs, Waltja).

Warrki Jarrinjaku ACRS Project Team. (2002) Warrki farrinjaku Fintangkamanu Purananjaku: working together everyone and listening. Aboriginal child rearing and associated research: a review of the literature (Canberra, Commonwealth Department of Family and Community Services).

Young, M., Lawrence, K., Orr, M., Nangala, I., Schaber, E. \& King, S. (in press) Waltja Tjutangku Palyapayi: organizational and individual journeys. Support document. Desert Knowledge CRC Project for National Centre for Vocational Education Research. 